\title{
Goniothalamus amplifolius B.J.Conn \& K.Q.Damas (Annonaceae), a new species from Papua New Guinea
}

\author{
Barry J. Conn ${ }^{1}$ and Kipiro Damas ${ }^{2}$ \\ ${ }^{1}$ National Herbarium of New South Wales, Mrs Macquaries Road, Sydney NSW 2000, Australia. \\ ${ }^{2}$ Papua New Guinea National Herbarium, PO Box 314, Lae, Papua New Guinea.
}

\begin{abstract}
The new species of Goniothalamus amplifolius B.J.Conn \& K.Q.Damas, from the Vanimo area of the West Sepik botanical region (Sandaun Province, Papua New Guinea), is here described, with habitat notes and a botanical illustration. Although the affinities of this species are unclear, it is morphologically similar to G. grandiflorus, but differs by its larger leaves and smaller flowers.
\end{abstract}

\section{Introduction}

Goniothalamus (Blume) Hook.f. \& Thomson (Annonaceae) is a large palaeotropical genus of more than 130 species (Saunders \& Chalermglin 2008). The genus is characterized by mostly axillary, usually pendant, bisexual flowers that consist of three sepals, and six petals arranged in two whorls. The outer whorl of petals is typically larger than the inner whorl, with the latter whorl connivent, forming a mitre-like dome over the numerous free stamens and carpels. The stamens have broad apical connectives and the fruits are apocarpous. The species of Goniothalamus that occur in Papua New Guinea are small subcanopy trees that are a frequent component of lowland forests. Prior to the discovery of Goniothalamus amplifolius, seven species were commonly recognized as occurring in Papua New Guinea, namely, G. aruensis Scheff. (Scheffer 1885), G. cauliflorus K.Schum. (Schumann 1889), G. grandiflorus Boerl. (Boerlage 1899) and G. imbricatus Scheff.(Scheffer 1885) - all common, wide-ranging species; G. caloneurus Miq.- only known from Milne Bay region; G. inaequilaterus K.Schum. \& Lauterb. - recorded from the Finschhafen area, Morobe region, and $G$. viridiflorus K.Schum. \& Lauterb.- once collected from near the Ramu River, Madang region (Schumann and Lauterbach 1900).

There have been no recent taxonomic studies of the genus in New Guinea, with recent workers focusing on the species of neighbouring regions: Australia (Jessup 1986), Borneo (Mat-Salleh 2001), Peninsula Malaysia (Saunders 2003), Sumatra, Indonesia (Saunders 2002) and Thailand (Saunders and Chalermglin 2008). The taxonomic status of other names published by Burck (1911), Lauterbach (1905), Lauterbach and 
Schumann (1898), Schumann and Lauterbach (1900) for the species occurring in the New Guinea region is poorly understood. A review of the genus in this region is urgently required.

The Papua New Guinean botanical regions cited in this paper follow Womersley (1978). The use of the term 'podium' for pedicellate flowers follows Conn (1995).

Goniothalamus amplifolius B.J.Conn \& K.Q.Damas, sp. nov.

a G. grandifloro (Warb.) Boerl. foliis longioribus (100-120 cm ) latioribusque $(7-13 \mathrm{~cm})$, costis petiolisque robustioribus, floribus brevioribus, petalis interioribus $20-25 \mathrm{~mm}$ longis differt.

Type: Papua New Guinea: West Sepik: near Vanimo, K.Q. Damas LAE79249, 31 Aug 1994 (holo: LAE289781; iso BRI, K, L, NSW, NY).

Small tree, up to $5 \mathrm{~m}$ high, usually single-stemmed, bearing distinct leaf scars. Leaves simple, alternate; petiole $3-3.5 \mathrm{~cm}$ long, swollen (pulvinate), up to $1.5 \mathrm{~cm}$ thick, abaxially convex beneath lamina, adaxially grooved; lamina narrowly oblong to narrowly obovate, 100-110(-120) cm long, 25-30(-35) cm wide (length to width ratio 3.3-4), abaxial surface finely puberulous, adaxial surface glabrous; base rounded, very shortly subcordate; margin entire; apex shortly and indistinctly acuminate (acumen c. $4 \mathrm{~mm}$ long) to subobtuse; midrib straight, stout, raised and prominent on abaxial surface, grooved on adaxial surface, especially towards base, almost flattened distally; secondary veins distinct and prominent, especially on abaxial surface, grooved adaxially, up to $27(-30)$ pairs, arising at an angle of 45-50 degrees to midrib; tertiary veins percurrent. Inflorescence cauliflorous; flowers in raised clusters, podiate (podium 20-25 mm long); bracts, inserted at base of podium, broadly ovate, distal bract largest (c. $3 \mathrm{~mm}$ long, c. $2.5 \mathrm{~mm}$ wide). Sepals 3, brownish green, almost half-way connate, each sepal triangular, c. $8 \mathrm{~mm}$ long, margin entire, apex obtuse to subacute, inner and outer surfaces densely covered with variously appressed, antrorse, or spreading, rusty red hairs $0.1-0.2 \mathrm{~mm}$ long. Petals arranged in 2 whorls; outer petals 3 , brownish green, narrowly ovate, $40-50 \mathrm{~mm}$ long, $11-12 \mathrm{~mm}$ wide near base (length to width ratio 3.6-4), 3-4 mm thick, margin entire, apex tapering, incurved on distal half, densely hairy as for sepals; inner petals 3 , valvate, connivent, broadly ovate to slightly rhombic, 20-25 mm long, 20-25 mm wide (length to width ratio c. 1), 1.5-2 $\mathrm{mm}$ thick, concave, slightly incurved, densely hairy (hairs \pm patent, $0.1-0.2 \mathrm{~mm}$ long). Stamens many, spirally arranged, flattened-oblong, 3-4.2 mm long, connectives pulvinate at apex, concealing anthers. Gynoecium apocarpous, glabrous; carpels many, c. 50, slightly asymmetrically fusiform, 3-3.5 mm long, with longitudinal groove ventrally; style very short, slightly incurved; stigma indistinct, ligulate to subcylindrical, c. $2.5 \mathrm{~mm}$ long. Fruit of separate fleshy carpels; mature carpels (apocarps) fusiform to ellipsoidal, dark reddish brown, glossy, 60-70 $\mathrm{mm}$ long, 20-22 $\mathrm{mm}$ diameter, base tapering; stipe 6-8 mm long, c. $7 \mathrm{~mm}$ diameter (basally), glabrous; seeds 6-7 per carpel, flattened ovoid, 10-12 mm long, glabrous. Figures $1 \& 2$.

Distribution: only known from Pasi Forest area, near Vanimo, West Sepik (Sandaun Province), Papua New Guinea.

Habitat: this is a common, albeit scattered species occurring in Closed Lowland Rainforest, at an elevation of about $200 \mathrm{~m}$.

Notes: a comparison of the morphology of the following three common species of 


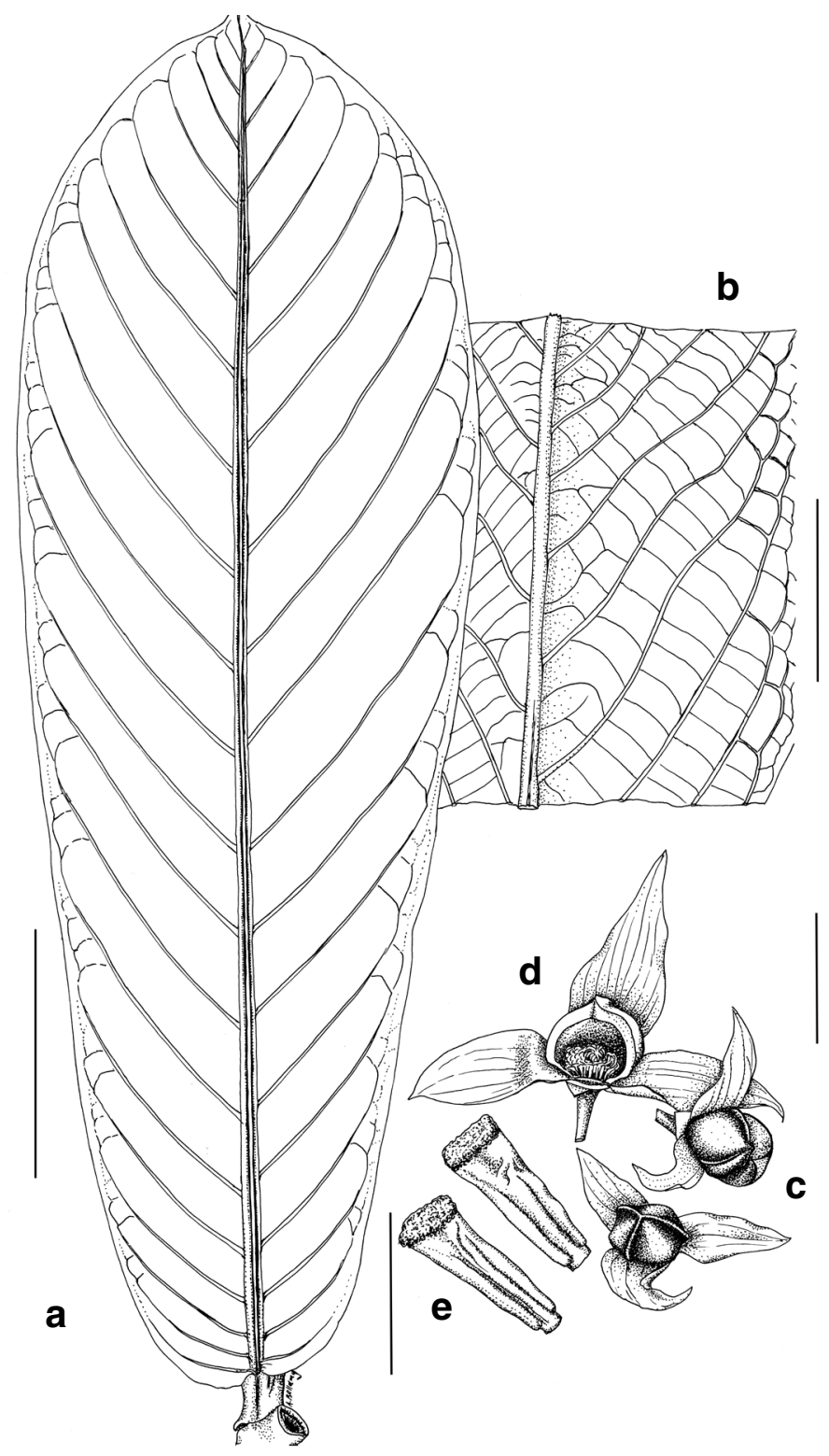

Fig.1. Goniothalamus amplifolius B.J.Conn \& K.Q.Damas. a, adaxial surface of leaf showing petiole, lamina, and primary and secondary venation; $\mathbf{b}$, detail of abaxial leaf lamina showing percurrent tertiary veins; c, 2 complete flowers showing 3 outer petals and 3 inner petals permanently connivent distally to form a mitre-like dome over reproductive organs; d, flower showing 3 outer petals, with one proximal inner petal removed to show androecium and gynoecium; and e, detail of two stamens. Scale: a $\& b=20 \mathrm{~cm} ; \mathrm{c}=50 \mathrm{~mm} ; \mathrm{d}=30 \mathrm{~mm} ; \mathrm{e}=4 \mathrm{~mm}$. All from Damas LAE79249. 


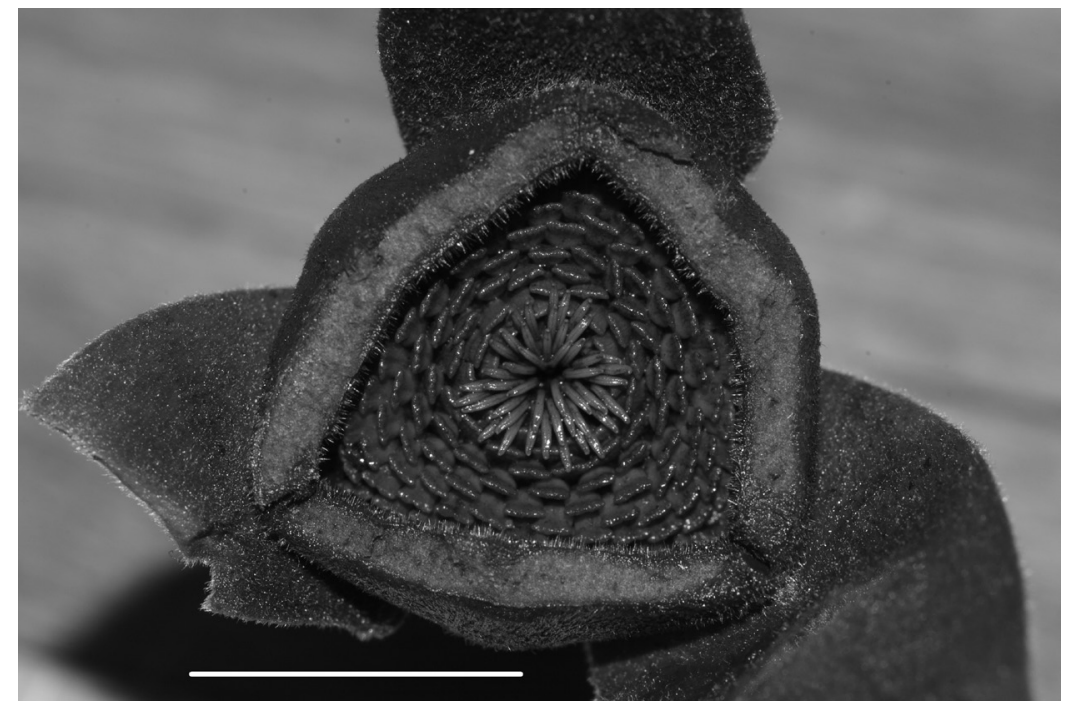

a

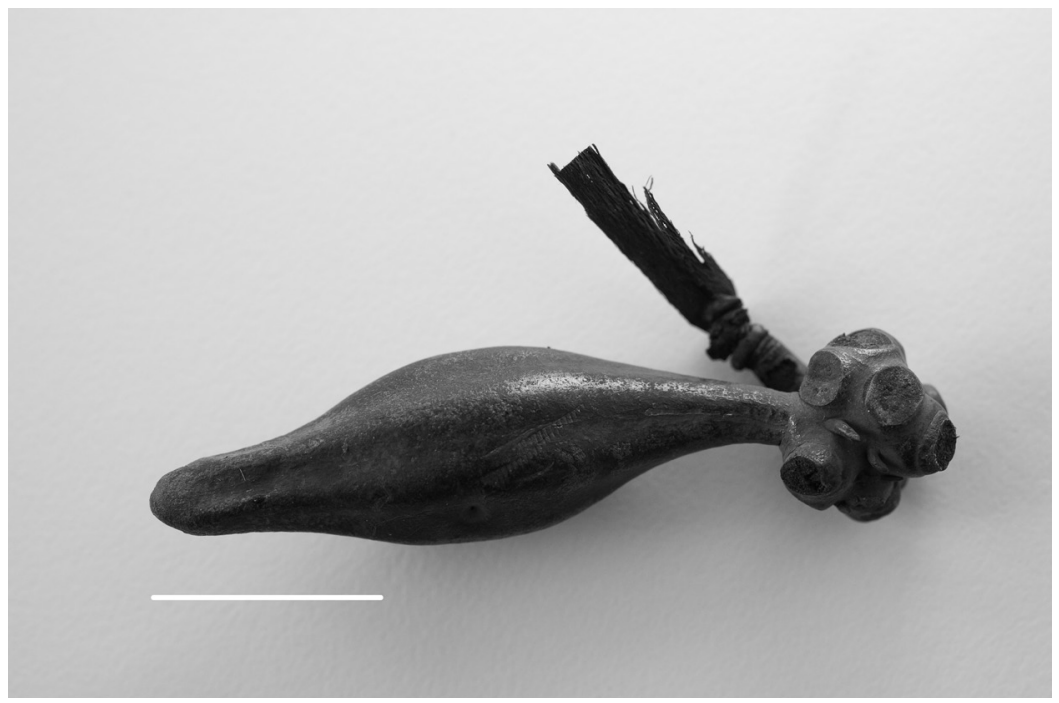

b

Fig. 2. Goniothalamus amplifolius B.J.Conn \& K.Q.Damas. a, distal half of inner corolla removed to revealed a top view of stamens surrounding gynoecium, with stigmas visible. Scale bar $=10 \mathrm{~mm}$; b, single, sessile fruiting apocarp attached to enlarged receptacle, other apocarps removed. Scale bar $=25 \mathrm{~mm}$. 
Goniothalamus in Papua New Guinea with G. amplifolius is based on direct field observations, evaluation of herbarium collections at LAE and NSW, and information included in the protologues (see references cited in the 'Introduction,' above). Goniothalamus amplifolius has leaves 100-110(-120) cm long, 25-30(-35) cm wide) whereas, those of G. grandiflorus are (16-)20-35(-50) cm long, 7-12(-13) cm wide, with the other common Papua New Guinean species, $G$. aruensis having leaves of a similar size to the latter species (16-30 cm long, (5-)7-12 cm wide). The outer petals of all three species are possibly similar in length (G. amplifolius: $40-50 \mathrm{~mm}$ long; G. grandiflorus: 20-40(-50) mm long; G. aruensis: 17-40(-50) mm long). Goniothalamus amplifolius has longer inner petals than G. grandiflorus (20-25 mm long and c. $17 \mathrm{~mm}$ long, respectively). Differences in fruit size suggest that G. amplifolius and G. grandiflorus have larger fruits (60-70 mm long, 20-22 mm diameter and c. $80 \mathrm{~mm}$ long, c. $40 \mathrm{~mm}$ diameter, respectively), whereas, the fruits of G. aruensis are smaller, 30-50 mm long and 10-15 $\mathrm{mm}$ diameter.

Goniothalamus cauliflorus and G. imbricatus are also both widespread species of lowland forests. However, both species are readily distinguished from G. amplifolius. Goniothalamus cauliflorus has laminas that tend to have fewer secondary veins (8-11 cf. up to 27(-30) pairs of secondary veins in G. amplifolius), and shorter outer and inner petals (c. $9 \mathrm{~mm}$ long and c. $5 \mathrm{~mm}$ long, respectively), whereas in G. amplifolius outer petals are $40-50 \mathrm{~mm}$ long and inner ones $20-25 \mathrm{~mm}$ long. Goniothalamus imbricatus has leaves with a long-attenuate base ( $G$. amplifolius with base of lamina rounded), carpels 6-9 (G. amplifolius at least 50) and seeds orbicular and 2-5 per apocarps (G. amplifolius with seeds flattened ovoid and 6-7 per apocarps). Morphological comparisons with other published names must await a more detailed review of the genus in New Guinea.

\section{Acknowledgments}

We thank Thomas Bilalu (previously Papua New Guinea Forest Research Institute, Lae) for drawing our attention to this species; Armstrong Bellamy (University of Technology Lae, Bulolo University Campus, Papua New Guinea) prepared the illustration of Goniothalamus amplifolius for publication; and Peter Wilson (NSW) kindly corrected the Latin diagnosis. Elizabeth Brown and Jaime Plaza (both NSW) kindly provided the photographs for figure $2 \mathrm{a}$ and $\mathrm{b}$, respectively. We thank the anonymous referees for providing detailed advice that has significantly improved this paper.

\section{References}

Boerlage JG (1899) Goniothalamus grandiflorus. Icones bogoriensis. Leiden 1: 136.

Burck W (1911) Anonaceae. Nova Guinea 8: 427-436.

Conn BJ (1995) Description of inflorescence axes in the genus Logania R.Br. (Loganiaceae). Kew Bulletin 50: 777-783.

Jessup LW (1986) The genus Goniothalamus (Blume) J.D.Hook. \& Thomson (Annonaceae) in Australia. Austrobaileya 2: 224-226.

Lauterbach KAG (1905) Anonaceae. Nachträge zur Flora der deutschen Schutzgebiete in der Südsee: mit Ausschluss Samoa's und der Karolinen. Leipzig pp. 265 \& 266 (Gebrüder Borntraeger: Leipzig)

Lauterbach KAG and Schumann KM (1898) Notizblatt des Koniglichen botanischen Gartens und Museums zu Berlin, Leipzig 2: 115. 
Mat-Salleh K (2001) New and noteworthy species of Bornean Goniothalamus (Annonaceae). Folia Malaysiana 2: 75-116.

Saunders RMK (2002) The genus Goniothalamus (Annonaceae) in Sumatra. Botanical Journal of the Linnean Society 139: 225-254.

Saunders RMK (2003) A synopsis of Goniothalamus (Annonaceae) in Peninsula Malaysia, with a description of a new species. Botanical Journal of the Linnean Society 142: 321-339.

Saunders RMK and Chalermglin P (2008) A synopsis of Goniothalamus species (Annonaceae) in Thailand, with description of three new species. Botanical Journal of the Linnean Society 156: 355-384.

Scheffer RHCC (1885) Sur quelques plantes nouvelles ou peu connues de l'Archipel Indien. Annales du Jardin botanique de Buitenzorg 2: 1-31.

Schumann KM (1889) Goniothalamus cauliflorus. Flora von Kaiser Wilhelms Land. Berlin 1: 48.

Schumann KM and Lauterbach CAG (1900) Anonaceae. Die Flora der deutschen Schutzgebiete in der Südsee, pp. 315-323. (Gebrüder Borntraeger: Leipzig)

Womersley JS (1978)(ed.) Handbooks of the Flora of Papua New Guinea, volume 1 (Melbourne University Press: Carlton)

Manuscript received 07 April 2010, accepted 08 June 2010 